Nurreza, et al/Jurnal Ekonomi Syariah Teori dan Terapan Vol. 6 No. 1 Januari: 125-141; PERAN BANK SYARIAH DALAM MENGGERAKKAN MOBILITAS SOSIAL (STUDI KASUS: PENGARUH PEMBIAYAAN BANK SYARIAH DAN BANK KONVENSIONAL TERHADAP PENYERAPAN TENAGA KERJA DI UMKM MELALUI PEMBIAYAAN UMKM DI INDONESIA)

\title{
PERAN BANK SYARIAH DALAM MENGGERAKKAN MOBILITAS SOSIAL (STUDI KASUS: PENGARUH PEMBIAYAAN BANK SYARIAH DAN BANK KONVENSIONAL TERHADAP PENYERAPAN TENAGA KERJA DI UMKM MELALUI PEMBIAYAAN UMKM DI INDONESIA)
}

\author{
Achmad l'tisham Naufal Nurreza \\ Departemen Ekonomi Syariah-Fakultas Ekonomi dan Bisnis-Universitas Airlangga \\ Email: nurrezanaufal@gmail.com \\ Eko Fajar Cahyono \\ Departemen Ekonomi Syariah-Fakultas Ekonomi dan Bisnis-Universitas Airlangga \\ Email: ekofajarc@feb.unair.ac.id
}

\begin{abstract}
:
Sharia bank is an agent in moving social mobility through given financing. The financing used for assisting a company or a business that needs financing, like working capital and investment. One of the businesses that need sharia bank financing is Micro, Small and Medium Enterprises (MSMEs). This research aimed to find out the influence of sharia and conventional bank financings on MSMEs' employment through MSMEs' financing in Indonesia using a path analysis technique, where MSMEs became an intervening variable. The result of the research showed that sharia and conventional bank financings had no effect on MSMEs' employment both directly or by MSMEs' financing.
\end{abstract}

Keywords :Sharia Financing, Conventional Financing, Employment, UMKM

\section{PENDAHULUAN}

Permasalahan kependudukan yang ada di Indonesia tidak hanya terjadi karena jumlah penduduk yang besar, tetapi juga karena pertumbuhan penduduk yang semakin tinggi. Pertumbuhan penduduk yang tinggi tersebut mengakibatkan tingginya angkatan kerja dan terbatasnya kesempatan kerja. Dengan terbatasnya kesempatan kerja mengakibatkan munculnya permasalahan terkait kependudukan karena mereka harus berupaya berebut kesempatan kerja yang tersedia. Kesempatan kerja di harapkan mampu untuk menjadi penggerak status sosial sekolompok orang, dimana ketika terjadi suatu perubahan sosial dinamakan mobilitas sosial. Mobilitas sosial juga sering 1) Jurnal ini merupakan bagian dari skripsi Achmad Istisham Nurreza, NIM: 041411431040, yang diuji pada tanggal 19 Oktober 2018.

dianalisis sebagai penentu kesejahteraan. Umumnya, mobilitas sosial dibedakan menjadi dua yaitu posisi sosial individu yang bergerak ke atas atau bergerak ke bawah semasa hidupnya. Dan yang kedua adalah posisi individu yang bergerak secara horizontal. Fenomena mobilitas sosial juga dapat terjadi ketika seseorang yang awalnya menganggur menjadi pekerja, dan begitu pula sebaliknya yang awalnya bekerja menjadi menganggur.

Pengangguran adalah kata yang sangat populer jika membicarakan tentang perkembangan pembangunan suatu daerah, dan khusus nya dalam masalah upaya peningkatan kesejahteraan masyarakat. Pengangguran merupakan fenomena sosial, memiliki masalah yang 
Nurreza, et al/Jurnal Ekonomi Syariah Teori dan Terapan Vol. 6 No. 1 Januari: 125-141; PERAN BANK SYARIAH

DALAM MENGGERAKKAN MOBILITAS SOSIAL (STUDI KASUS: PENGARUH PEMBIAYAAN BANK SYARIAH DAN BANK KONVENSIONAL TERHADAP PENYERAPAN TENAGA KERJA DI UMKM MELALUI PEMBIAYAAN UMKM DI INDONESIA)

kompleks, karena berkaitan dengan aspek sosial, ekonomi, budaya, dan aspek lainnya. Indonesia merupakan negara yang sedang berkembang, dan termasuk negara dengan memiliki jumlah penduduk terbesar di dunia. Namun, pertumbuhan penduduk yang tinggi, menimbulkan kesulitan kepada negara-negara berkembang untuk mempertinggi tingkat kesejahhteraan masyarakat. Perkembangan penduduk yang semakin cepat dan dalam jumlah yang besar sekali dapat menimbulkan beberapa masalah yang baru dan salah satunya adalah pengangguran. Pertumbuhan penduduk yang semakin pesat menyebabkan masalah pengangguran menjadi bertambah buruk. pengangguran akan memengaruhi perekonomian negara dalam jangka panjang, yaitu meningkatnya jumlah pengangguran akan menyebabkan turunnya tingkat pertumbuhan ekonomi. Menurut Zagler (2007) dalam Sari Lestari (2013:158) penurunan tingkat pertumbuhan ekonomi akan menyebabkan penurunan dalam berbagai bidang lainnya salah satunya yang penting adalah penurunan dalam kualitas modal manusia (Zulfiqar et al., 2012), dan rendahnya kualitas sumber daya manusia akan memengaruhi kondisi pembangunan yang berkelanjutan. Karena itu pengurangan tingkat pengangguran merupakan upaya yang niscaya dilakukan, sehingga ketika peluang untuk upaya tersebut ada, perlu dioptimalisasi.
Dapat dilihat bahwa pengangguran memiliki pengaruh yang negatif terhadap tingkat pertumbuhan ekonomi daerah dan negara tersebut. Maka dari itu pemerintah selalu menggerakkan berbagai solusi dan kebijakan yang digunakan untuk mengatasi masalah pengangguran itu sendiri. Salah satu nya adalah menjadikan UMKM sebagai salah satu solusi atas pengangguran tersebut. Usaha kecil dan informal merupakan sektor usaha yang telah terbukti berperan strategis atau penting dalam mengatasi akibat dan dampak dari krisis ekonomi yang pernah melanda Indonesia di tahun 1997. Di sisi lain, sektor usaha kecil dan informal juga telah mampu memberikan kontribusi dalam mendorong pertumbuhan ekonomi Indonesia selama ini. Kedudukan yang strategis dari sektor usaha kecil dan informal tersebut juga karena sektor ini mempunyai beberapa keunggulan dibandingkan usaha besar/menengah. Keunggulan-keunggulan sektor ini antara lain kemampuan menyerap tenaga kerja dan menggunakan sumberdaya lokal, serta usahanya relatif bersifat fleksibel (Supriyanto.2006:1)

Ada beberapa masalah umum yang dihadapi oleh pengusaha kecil dan menengah seperti keterbatasan modal kerja dan modal investasi, kesulitan mendapatkan bahan baku dengan kualitas yang baik dengan harga terjangkau, keterbatasan teknologi, sumber daya manusia dengan kualitas yang 
Nurreza, et al/Jurnal Ekonomi Syariah Teori dan Terapan Vol. 6 No. 1 Januari: 125-141; PERAN BANK SYARIAH DALAM MENGGERAKKAN MOBILITAS SOSIAL (STUDI KASUS: PENGARUH PEMBIAYAAN BANK SYARIAH DAN BANK KONVENSIONAL TERHADAP PENYERAPAN TENAGA KERJA DI UMKM MELALUI PEMBIAYAAN UMKM DI INDONESIA)

baik(manajemen dan teknik produksi), informasi pasar, serta kesulitan dalam pemasaran. Tingkat intensitas dan sifat dari masalah-masalah tersebut bisa berbeda tidak hanya menurut jenis produk atau pasar yang dilayani tetapi juga berbeda antarwilayah, antarsentra, antarsektor/antars ubsektor atau jenis kegiatan, dan antar unit usaha dalam kegiatan/sektor yang sama (Tambunan, 2002:73).Pentingnya dana bagi kegitan usaha untuk UMKM maka perlu adanya kerjsama yang baik antara pihak bank sebagai lembaga pemberi krdit dengan UMKM. Kerjasama ini perlu dilakukan agar permasalahan di antara kedua belah pihak tersebut bisa diatasi dan saling menguntungkan (Suryana, 2003 dalam Rahmad 2015). Disinilah peran bank baik syariah maupun konvensional dibutuhkandalam menunjang pekembangan UMKM melalui pembiayaan dan investasi. Sebagaimana bank merupakan salah satu agen pembangunan (agent of development) dalam kehidupan bernegara, karena fungsi utama dari bank adalah sebagai lembaga intermediasi kevangan (financial intermediary institution), yaitu lembaga yang menghimpun dana dari masyarakat dalam bentuk simpanan dan menyalurkannya kembali kepada masyarakat dalam bentuk kredit atau pembiayaan. Fungsi perbankan sebagai lembaga intermediasi keuangan juga menjadi konsen dari perbankan syariah, disamping sebagai lembaga yang mengelola zakat, infak, dan sedekah (ZIS) (Kara Muslimin, 2013:315). Berikut merupakan grafik data pembiayaan bank syariah dan bank konvensional pada tahun 2015-2017:

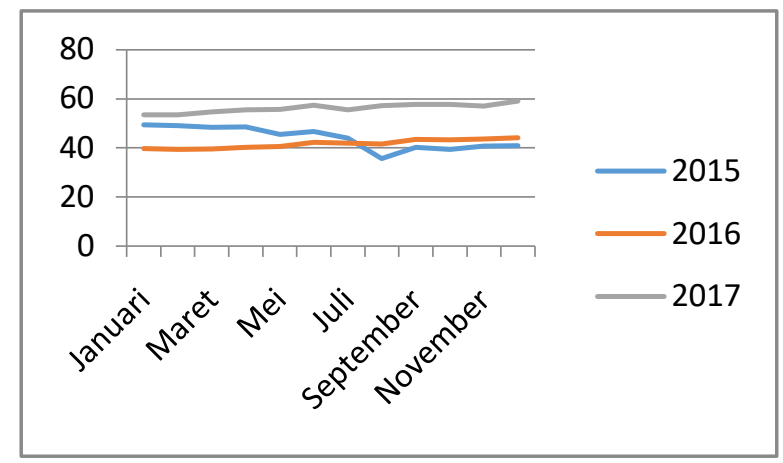

Sumber: Otoritas Jasa Keuangan, data diolah

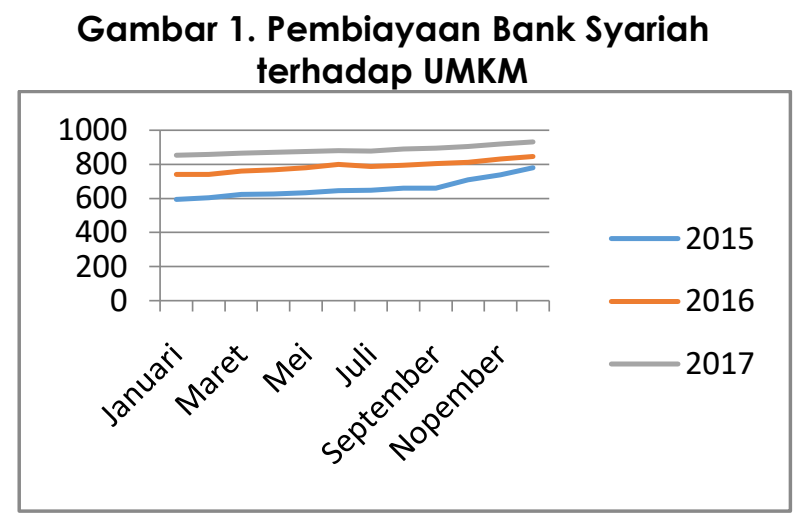

Sumber: Otoritas Jasa Keuangan, data diolah

\section{Gambar 2. Pembiayan Bank Konvensional terhadap UMKM}

Dapat dilihat bahwa jumlah pembiayaan bank syariah dan bank konvensional terhadap umkm berdasarkan ruang lingkup nasional. Pemberian kredit atau permodalan modal kepada pelakU UMKM, secara langsung akan mempengaruhi volume usaha bila hal tersebut digunakan menjadi modal kerja. Jika kredit tersebut 
Nurreza, et al/Jurnal Ekonomi Syariah Teori dan Terapan Vol. 6 No. 1 Januari: 125-141; PERAN BANK SYARIAH

DALAM MENGGERAKKAN MOBILITAS SOSIAL (STUDI KASUS: PENGARUH PEMBIAYAAN BANK SYARIAH DAN BANK KONVENSIONAL TERHADAP PENYERAPAN TENAGA KERJA DI UMKM MELALUI PEMBIAYAAN UMKM DI INDONESIA)

digunakan untuk investasi atau untuk melakukan diversifikasi usaha, maka akan meningkatkan kesempatan kerja, yang pada akhirnya akan menambah volume usaha juga. Pertambahan volume usaha tersebut akan dapat meningkatkan pendapatan bagi UKM maupun tenaga kerja yang bekerja pada perusahaan tersebut (Zamroni, 2013:227)

Berdasarkan latar belakang yang telah dijelaskan maka,rumusan masalah dalam penelitian ini adalah:

1.Apakah pembiayaan bank syariah berpengaruh terhadap penyerapan tenaga kerja di UMKM melalui pembiayaan UMKM di Indoensia?

2.Apakah pembiayaan bank konvensional berpengaruh terhadap penyerapan tenaga kerja di UMKM melalui pembiayaan umkm di Indoensia?

3.Apakah pembiayaan bank syariah berpengaruh terhadap penyerapan tenaga kerja di UMKM di Indonesia?

4.Apakah pembiayaan bank konvensional berpengaruh terhadap penyerapan tenaga kerja di UMKM di Indonesia?

5.Apakah pertumbuhan UMKM berpengaruh terhadap penyerapan tenaga kerja UMKM di Indonesia?

Adapun tujuan penelitian yang akan diperoleh dari penelitian ini adalah sebagai berikut:

1.Mengetahui peran pembiayaan bank syariah dalam mengatasi penyerapan tenaga kerja di umkm melalui pembiayaanUMKM di Indoensia.

2.Mengetahui peran pembiayaan bank konvensional dalam mengatasi penyerapan tenaga kerja di umkm melalui pembiayaan UMKM di Indoensia.

3.Mengetahui peran pembiayaan bank syariah terhadap penyerapan tenaga kerja di UMKM di Indonesia.

4.Mengetahui peran bank konvensional terhadap penyerapan tenaga kerja di UMKM di Indonesia.

5.Mengetahui pengaruh pertumbuhan UMKM terhadap penyerapan tenaga kerja UMKM di Indonesia.

\section{LANDASAN TEORI}

\section{Mobilitas Sosial}

Giddens (2001:300) mendefinisikan mobilitas sosial sebagai pergerakan individu-individu dan kelompok-kelompok di antara kelompok sosial-ekonomi yang berbeda. Artinya, individu-individu atau kelompok - kelompok mengalami perpindahan dalam posisi sosial-ekonomi yang berbeda.

Dalam mempelajari mobilitas sosial, perhatian kita tidak hanya tertuju pada perpindahan posisi sosial individu-individu, tetapi juga pada konsekuensi dari perpindahan tersebut bagi kelompokkelompok sosial dan struktur sosial secara keseluruhan dimana individu-individu tersebut berpindah (Pattinasarany, 2016:35). 
Nurreza, et al/Jurnal Ekonomi Syariah Teori dan Terapan Vol. 6 No. 1 Januari: 125-141; PERAN BANK SYARIAH

DALAM MENGGERAKKAN MOBILITAS SOSIAL (STUDI KASUS: PENGARUH PEMBIAYAAN BANK SYARIAH DAN BANK KONVENSIONAL TERHADAP PENYERAPAN TENAGA KERJA DI UMKM MELALUI PEMBIAYAAN UMKM DI INDONESIA)

\section{Pengangguran}

Menurut Sadono Sukirno (1994)

dalam Faisal (2016:64), pengangguran adalah suatu keadaan di mana seseorang yang tergolong dalam angkatan kerja ingin mendapatkan pekerjaan tetapi belum dapat memperolehnya. Sehingga penganguran adalah keadaan dimana orang ingin bekerja namun tidak mendapat pekerjaan.

Faktor-faktor yang mempengaruhi tingkat pengangguran menurut Marhaeni dan Manuati (2004), yaitu sebagai berikut:

a. Tingkat upah, dimana tingkat upah memegang peranan penting atau sangat berpengaruh besar dalam kondisi ketenagakerjaan.

b. Teknologi, penggunaan teknologi yang tepat guna akan mempengaruhi permintaan tenaga kerja sehingga akan meningkatkan jumlah pengangguran.

c. Fasilitas modal, fasilitas modal mempengaruhi permintaan tenaga kerja melalui dua sisi. Pengaruh substitutif, dimana bertambahnya modal akan mengurangi permintaan tenaga kerja. Pengaruh komplementer, dimana bertambahnya modal akan membutuhkan tenaga kerja yang lebih banyak untuk mengelola modal yang tersedia.
Struktur perekonomian, perubahan struktur ekonomi menyebabkan penurunan permintaan tenaga kerja.

Pengangguran sering diartikan sebagai orang yang ingin bekerja namun tidak memiliki pekerjaan. Dan menurut Franita Riska (2016:89) Pengangguran terdiri dari 3 macam:

a. Pengangguran Terselubung tenaga kerja yang kurang dari 35 jam perminggu.

b. Setengah Menganggur adalah tenaga kerja yang tidak bekerja secara maksimal karena suatu alasan tertentu.

c. Pengangguran Terbuka adalah tenaga kerja yang sungguh-sungguh tidak memiliki pekerjaan.

Tabel 1.

Pengelompokkan UMKM berdasarkan nilai aset dan hasil penjualan

\begin{tabular}{|c|c|c|}
\hline $\begin{array}{c}\text { Skala } \\
\text { Usaha }\end{array}$ & Nilai Aset & Hasil Penjualan \\
\hline Mikro & $<$ Rp 50 juta & $<$ Rp 300 juta \\
\hline Kecil & $\begin{array}{c}\text { Rp } 50 \text { juta - Rp } \\
500 \text { juta }\end{array}$ & $\begin{array}{c}\text { Rp } 300 \text { juta }- \text { Rp } \\
2.5 \text { miliar }\end{array}$ \\
\hline $\begin{array}{c}\text { Meneng } \\
\text { ah }\end{array}$ & $\begin{array}{c}500 \text { juta }- \text { Rp } 10 \\
\text { miliar }\end{array}$ & $\begin{array}{c}\text { Rp } 2.5 \text { miliar - Rp } \\
50 \text { miliar }\end{array}$ \\
\hline Sumber: & Undang-undang Republik \\
\hline
\end{tabular}

Indonesia Nomor 20 Tahun 2008

Berdasarkan Undang-Undang Republik Indonesia Nomor 20 Tahun 2008 tentang Usaha Mikro, Kecil, dan Menengah (UMKM), UMKM didefinisikan sebagai berikut:

1.Usaha Mikro adalah usaha produktif milik orang perorangan dan/atau badan usaha perorangan yang memenuhi 
Nurreza, et al/Jurnal Ekonomi Syariah Teori dan Terapan Vol. 6 No. 1 Januari: 125-141; PERAN BANK SYARIAH

DALAM MENGGERAKKAN MOBILITAS SOSIAL (STUDI KASUS: PENGARUH PEMBIAYAAN BANK SYARIAH DAN BANK KONVENSIONAL TERHADAP PENYERAPAN TENAGA KERJA DI UMKM MELALUI PEMBIAYAAN UMKM DI INDONESIA)

kriteria usaha mikro sebagaimana diatur dalam Undang-Undang ini.

2.Usaha Kecil adalah usaha ekonomi produktif yang berdiri sendiri, yang dilakukan oleh orang perorangan atau badan usaha yang bukan merupakan anak perusahaan atau bukan cabang perusahaan yang dimiliki, dikuasai, atau menjadi bagian baik langsung maupun tidak langsung dari Usaha Menengah atau Usaha Besar yang memenuhi kriteria usaha kecil sebagaimana dimaksud dalam Undang-Undang ini.

3.Usaha Menengah adalah usaha ekonomi produktif yang berdiri sendiri, yang dilakukan oleh orang perorangan atau badan usaha yang bukan merupakan anak perusahaan atau cabang perusahaan yang dimiliki, dikuasai, atau menjadi bagian baik langsung maupun tidak langsung dengan usaha kecil atau usaha besar dengan jumlah kekayaan bersih atau hasil penjualan tahunan sebagaimana diatur dalam Undang-Undang ini.

4.Usaha Besar adalah usaha ekonomi produktif yang dilakukan oleh badan usaha dengan jumlah kekayaan bersihatau hasil penjualan tahunan lebih besar dari Usaha Menengah, yang meliputi usaha nasional milik negara atau swasta, usaha patungan, dan usaha asing yang melakukan kegiatan ekonomi di Indonesia.

5.Dunia Usaha adalah Usaha Mikro, Usaha Kecil, Usaha Menengah, dan Usaha Besar yang melakukan kegiatan ekonomi di Indonesia dan berdomisili di Indonesia

Menurut Roswita (2015:80), pentingnya UMKM sebagai salah satu sumber pertumbuhan kesempatan kerja di Indonesia tidak hanya tercerminkan pada kondisi statis, yakni jumlah orang yang bekerja dikelompok usaha tersebut yang jauh lebih banyak daripada yang diserap oleh usaha besar, tetapi juga dapat dilihat pada kondisi dinamis, yakni dari laju kenaikannya setiap tahun yang lebih tinggi daripada usaha besar.

2. Bank Syariah

Dalam UU No. 21 tahun 2008 mengenai Perbankan Syariah mengemukakan pengertian perbankan syariah dan pengertian bank syariah. Perbankan Syariah yaitu segala sesuatu yang menyangkut bank syariah dan unit usaha syariah, mencakup kelembagaan, mencakup kegiatan usaha, serta tata cara dan proses di dalam melaksanakan kegiatan usahanya. Bank Syariah adalah bank yang menjalankan kegiatan usahanya dengan didasarkan pada prisnsip syariah dan menurut jenisnya bank syariah terdiri dari BUS (Bank Umum Syariah), UUS (Unit Usaha Syariah) dan BPRS (Bank Pembiayaan Rakyat Syariah) (Otoritas Jasa Kevangan).

\section{Bank Konvensional}

Perbankan Indonesia dalam menjalankan fungsinya berasaskan prinsip kehati-hatian. Fungsi utama perbankan Indonesia adalah sebagai penghimpun dan penyalur dana 
Nurreza, et al/Jurnal Ekonomi Syariah Teori dan Terapan Vol. 6 No. 1 Januari: 125-141; PERAN BANK SYARIAH

DALAM MENGGERAKKAN MOBILITAS SOSIAL (STUDI KASUS: PENGARUH PEMBIAYAAN BANK SYARIAH DAN BANK KONVENSIONAL TERHADAP PENYERAPAN TENAGA KERJA DI UMKM MELALUI PEMBIAYAAN UMKM DI INDONESIA)

masyarakat serta bertujuan untuk menunjang pelaksanaan pembangunan nasional dalam rangka meningkatkan pemerataan pembangunan dan hasilhasilnya, pertumbuhan ekonomi dan stabilitas nasional, kearah peningkatan taraf hidup rakyat banyak (Bank Indonesia).

Menurut UU No. 10 pasal 1 tahun 1998, Bank adalah badan usaha yang menghimpun dana dari masyarakat dalam bentuk simpanan dan menyalurkannya kepada masyarakat dalam bentuk kredit dan atau bentuk-bentuk lainnya dalam rangka meningkatkan taraf hidup rakyat banyak.

4. Pembiayaan Bank Syariah

Menurut Rahardi (2010:103), dalam penyaluran dana, bank syariah menyalurkan melalui pembiayaan (financing) yang berupa :

1.Pembiayaan dengan prinsip jual-beli (bai"):

a.Murabahah

Akad pembiayaan suatu barang dengan menegaskan harga belinya kepada pembeli dan pembeli membayarnya dengan harga yang lebih sebagai keuntungan yang disepakati.

b.Istishna

Akad pembiayaan barang dalam bentuk pemesanan pembuatan barang tertentu yang disepakati antara pemesan atau pembeli (mustashni') dan penjual atau pembuat (shani').

c.Salam 
Nurreza, et al/Jurnal Ekonomi Syariah Teori dan Terapan Vol. 6 No. 1 Januari: 125-141; PERAN BANK SYARIAH

DALAM MENGGERAKKAN MOBILITAS SOSIAL (STUDI KASUS: PENGARUH PEMBIAYAAN BANK SYARIAH DAN BANK KONVENSIONAL TERHADAP PENYERAPAN TENAGA KERJA DI UMKM MELALUI PEMBIAYAAN UMKM DI INDONESIA)

5.Hiwalah (anjak piutang)

Adalah akad pengalihan hutang dari satu pihak yang berhutang kepada pihak lain yang wajib menanggung atau membayarnya.

6.Rahn (gadai)

Adalah menahan barang sebagai jaminan atas hutang.

\section{Pembiayaan Bank Konvensional}

Pengelompokan kredit menurut Kasmir (2008:103-106) dalam Wulandary (2015) dapat dilihat dari :

1. Dilihat dari segi kegunaan

a. Kredit Investasi, biasanya digunakan untuk keperluan perluasan usaha atau untuk keperluan rehabilitas. Contoh kredit investasi misalnya untuk membangun pabrik atau membeli mesin-mesin. Pendek kata masa pemakaiannya untuk suatu periode relatif cukup lama.

b. Kredit Modal Kerja, digunakan untuk keperluan meningkatkan produksi dalam operasionalnya. Sebagai contoh kredit modal kerja diberikan untuk membeli bahan baku, membayar gaji pegawai atau biayabiaya lainnya yang berkaitan dengan proses produksi perusahaan.

2. Dilihat dari segi tujuan kredit

a. Kredit Produktif, kredit yang digunakan untuk meningkatkan usaha atau produksi atau investasi. Kredit ini diberikan untuk menghasilkan barang atau jasa. Sebagai contohnya kredit untuk membangun barang, kredit pertanian atau kredit pertambangan menghasilkan bahan tambang atau kredit industri lainnya.

b. Kredit Konsumtif, kredit yang digunakan untuk dikonsumsi secara pribadi. Dalam kredit ini tidak ada pertambahan barang dan jasa yang dihasilkan, karena memang untuk digunakan atau dipakai oleh seseorang atau badan usaha. Sebagai contoh kredit untuk perumahan, kredit mobil pribadi, kredit perabotan rumah tangga, atau kredit konsumtif lainnya.

c. Kredit Perdagangan, kredit yang digunakan untuk perdagangan, biasanya digunakan untuk membeli barang dagangan yang pembayarannya diharapkan dari hasil penjualan barang dagangan tersebut. Kredit ini seringkali digunakan kepada supplier atau agenagen perdagangan yang akan membeli barang dalam jumlah besar. Contoh kredit ini misalnya kredit ekspor dan impor.

3. Dilihat dari segi jangka waktu

a. Kredit Jangka Pendek, merupakan kredit yang dimiliki jangka waktu kurang dari 1 tahun atau paling lama 1 tahun dan biasanya digunakan untuk keperluan modal kerja. Contohnya untuk peternakan misalnya kredit peternakan ayam jika untuk pertanian misalnya tanaman padi atau palawijaya.

b. Kredit Jangka Menengah, merupakan kredit yang jangka waktu kreditnya berkisar antara 1 tahun sampai 3 tahun, biasanya untuk investasi. Contoh kredit untuk 
Nurreza, et al/Jurnal Ekonomi Syariah Teori dan Terapan Vol. 6 No. 1 Januari: 125-141; PERAN BANK SYARIAH

DALAM MENGGERAKKAN MOBILITAS SOSIAL (STUDI KASUS: PENGARUH PEMBIAYAAN BANK SYARIAH DAN BANK KONVENSIONAL TERHADAP PENYERAPAN TENAGA KERJA DI UMKM MELALUI PEMBIAYAAN UMKM DI INDONESIA)

pertanian seperti jeruk atau peternakan kambing.

c. Kredit Jangka Panjang, merupakan kredit yang masa pengembaliannya paling panjang. Kredit jangka panjang waktu pengembaliannya diatas 3 tahun atau 5 tahun. Biasanya kredit ini untuk investasi jangka panjang seperti perkebunan karet, kelapa sawit atau manufaktur dan untuk kredit konsumtif seperti kredit perumahan.

4. Dilihat dari segi jaminan

a. Kredit dengan Jaminan, kredit yang diberikan dengan suatu jaminan. Jaminan tersebut dapat berbentuk barang berwujud atau tidak berwujud atau jaminan orang. Artinya setiap kredit yang dikeluarkan akan dilindungi senilai jaminan yang diberikan si calon debitur. Contohnya kredit jaminan dokumen, kredit agunan efek, kredit agunan orang.

b. Kredit Tanpa Jaminan, merupakan kredit yang diberikan tanpa jaminan barang atau tertentu. Kredit ini diberikan dengan melihat prospek usaha dan karakter serta loyalitas atau nama baik si calon debitur selama ini.

\section{Dilihat dari sektor usaha}

a. Kredit Pertanian, merupakan kredit yang dibiayai untuk sektor perkebunan atau pertanian rakyat. Hal ini dapat berupa jangka pendek maupun jangka panjang.

b. Kredit Peternakan, hal ini untuk jangka pendek misalnya peternakan ayam dan jangka panjang seperti kambing dan sapi.

c. Kredit Industri, kredit untuk membiayai industri kecil, menengah, besar. d. Kredit Pertambangan, jenis usaha tambang yang biasanya dibiayai yaitu jangka panjang misalnya, pertambangan minyak, emas, timah.

e. Kredit Pendidikan, merupakan kredit yang diberikan untuk membangun sarana dan prasarana pendidikan atau dapat pula kredit untuk mahasiswa.

f. Kredit profesi, diberikan kepada professional, seperti dosen, dokter, atau pengacara.

g. Kredit Perumahan, kredit untuk membiayai pembangunan atau pembelian rumah.

h. Kredit sektor-sektor lainnya seperti kredit ekspor-impor.

\section{Metode Penelitian}

Penelitian ini menggunakan pendekatan penelitian kuantitatif deskriptif yaitu untuk untuk menjawab rumusan masalah serta tujuan penelitian yaitu peran pembiayaan bank syariah terhadap pengangguran melalui pembiayaan umkm. Penekanan penelitian yang digunakan dalam penelitian ini adalah pendeketan penelitian kuantitaif. Penelitian kuantitaif merupakan penelitian terstruktur dan mengkuantifikasikan data untuk dapat digenerealisasikan (Anshori dan Iswati, 2009:19). Dalam penelitian kuantitatif, masalah yang dibawa oleh peneliti harus sudah jelas. Menurut Tuckman, setiap penelitian yang akan dilakukan harus selalu berangkat dari masalah, walaupun diakui bahwa memilih masalah penelitian 
Nurreza, et al/Jurnal Ekonomi Syariah Teori dan Terapan Vol. 6 No. 1 Januari: 125-141; PERAN BANK SYARIAH

DALAM MENGGERAKKAN MOBILITAS SOSIAL (STUDI KASUS: PENGARUH PEMBIAYAAN BANK SYARIAH DAN BANK KONVENSIONAL TERHADAP PENYERAPAN TENAGA KERJA DI UMKM MELALUI PEMBIAYAAN UMKM DI INDONESIA)

merupakan hal yang paling sulit dalam proses penelitian (Sugiyono, 2014:52).

Tujuan metode kuantitatif adalah menunjukan pengaruh antar variabel, mencari teori, mencari generalisasi yang mempunyai nilai prediktif (Sugiyono, 2014:14). Pendekatan kuantitatif dilakukan dengan menggunakan model ekonometrika gabungan analisis matematis, teori ekonomi dan statistik.

Variabel yang digunakan dalam penelitian ini adalah sebagai berikut:

1.Variabel Independen (variabel eksogen/bebas) adalah variabel yang mempengaruhi atau yang menjadi sebab perubahan atau timbulnya variabel dependen (terikat) (Sugiyono, 2009: 39). Variabel eksogen pada penelitian ini adalah pembiayaan bank syariah dan pembiayaan konvensional

2.Variabel endogen yaitu variabel tidak bebas atau bergantung, variabel ini seering disebut juga sebagai variabel output, kriteria, kose (Anshori dan Iswati, 2009:58), variabel endogen dalam penelitian ini adalah penyerapan tenaga kerja di umkm.

3.Variabel intervening (variabel penyela/antara), adalah variabel yang secara teoritis mempengaruhi hubungan antara variabel independen dengan variabel dependen menjadi hubungan tidak langsung dan tidak dapat diamati atau diukur. Trucman (1988) dalam Sugiyono (2009: 41). Jadi bisa dikatakan bahwa variabel intervening dapat menjadi variabel eksogen maupun endogen. Variabel intervening dalam penelitian ini adalah Usaha Mikro Kecil, dan Menengah.

IV. Analisis Data dan Pengujian
Hipotesis

Pengujian Asumsi

a. normalitas

Tabel 2.

Hasil Uji Normalitas

\begin{tabular}{|c|c|c|c|c|c|}
\hline Variable & $\begin{array}{l}\text { o } \\
\text { bs }\end{array}$ & $\begin{array}{l}\text { Ske } \\
\text { w }\end{array}$ & $\begin{array}{l}\text { Kurt } \\
\text { osis }\end{array}$ & $\begin{array}{l}\text { Adj } \\
\text { chi2 } \\
(2)\end{array}$ & $\begin{array}{l}\text { Pro } \\
b>c \\
\text { hi2 }\end{array}$ \\
\hline $\begin{array}{c}\text { Pembiaya } \\
\text { an bank } \\
\text { syariah }\end{array}$ & 35 & $\begin{array}{c}0.55 \\
07\end{array}$ & $\begin{array}{c}0.00 \\
07\end{array}$ & 9.71 & $\begin{array}{c}0.00 \\
78\end{array}$ \\
\hline $\begin{array}{l}\text { Pembiaya } \\
\text { an bank }\end{array}$ & & 0.37 & 0.00 & & 0.01 \\
\hline $\begin{array}{c}\text { konvensio } \\
\text { anal }\end{array}$ & 35 & 51 & 17 & 8.93 & 15 \\
\hline UMKM & 35 & $\begin{array}{c}0.02 \\
12\end{array}$ & $\begin{array}{c}0.88 \\
73\end{array}$ & 5.19 & $\begin{array}{c}0.07 \\
48\end{array}$ \\
\hline $\begin{array}{c}\text { Tenaga } \\
\text { Kerja }\end{array}$ & 35 & $\begin{array}{c}0,06 \\
54\end{array}$ & $\begin{array}{c}0.80 \\
14\end{array}$ & 3.74 & $\begin{array}{c}0.15 \\
40\end{array}$ \\
\hline
\end{tabular}

Sumber: data diolah penelliti

Dapat dilihat bahwa nilai prob>chi2 pada variabel pembiayaan bank syariah sebesar 0,0078, variabel pembiayaan bank konvensional sebesar 0.0115 , variabel UMKM sebesar 0.0748, variabel tenaga kerja sebesar 0.1540. sehingga data observasi pada penelitian ini telah menguji uji asumsi normalitas. Dari data diatas data yang terdistribusi normal adalah data pada variabel UMKM dan tenaga kerja, sedangkan data pada variabel 
Nurreza, et al/Jurnal Ekonomi Syariah Teori dan Terapan Vol. 6 No. 1 Januari: 125-141; PERAN BANK SYARIAH DALAM MENGGERAKKAN MOBILITAS SOSIAL (STUDI KASUS: PENGARUH PEMBIAYAAN BANK SYARIAH DAN BANK KONVENSIONAL TERHADAP PENYERAPAN TENAGA KERJA DI UMKM MELALUI PEMBIAYAAN UMKM DI INDONESIA)

pembiayaan bank syariah dan bank konvensional tidak terdistribusi normal. Menurut (Latan, 2014:182), bahwa berbagai cara dapat dilakukan jika data yang di analisis tidak terdistribusi normal antara lain dengan mentransformasi data ke dalam bentuk lain seperti logaritma, akar kuadrat (square root) dan sebagainya, Namun jika sampel yang kita gunakan besar, maka pelanggara terhadap asumsi ini tidak akan berpengaruh terhadap hasil estimasi karena berdasarkan pada central limit theorem. Sehingga terkait data variabel pembiayaan bank syariah dan bank konvensional yang tidak terdistribusi normal dalam penelitian ini tidak dipermasalahkan.

\section{b. Uji Heterokedaskisitas}

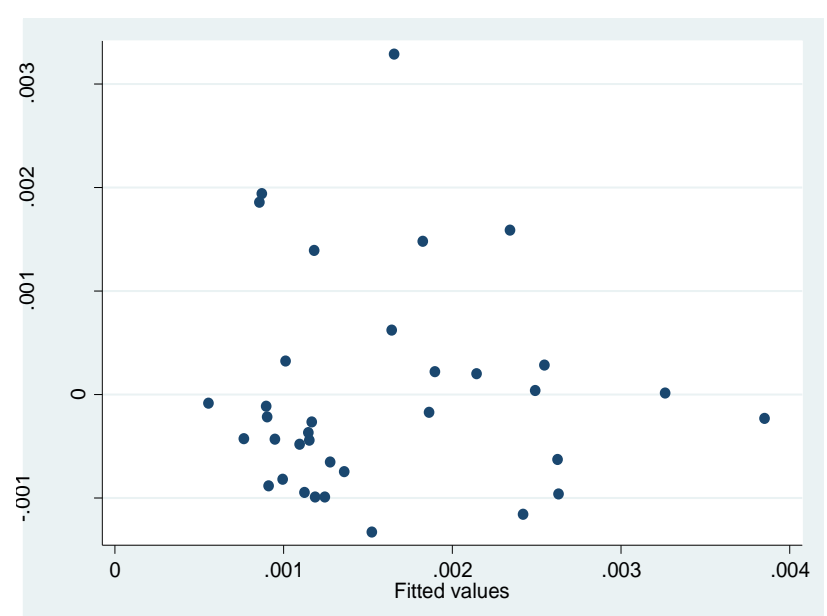

Sumber: data diolah peneliti

Data dikatan tidak terjadi heterokedastisitas jika mempunyai nilai pada prob>chi2 sebesar $>0,5$. dalam penelitian in prob>chi2 sebesar 0.6514 .

\section{c. Uji Autokorelasi}

estat dwatson

Durbin-Watson d-statistic $(5,35)=2.000226$

Berdasarkan hasil uji durbin watson dapat dilihat bahwa angka DW sebesar 2.000226 . hal ini menunjukkan bahwa nilai DW berada pada saerah yang aman. Sehingga pada penelitian ini dapat disimpulkan bahwa tidak terdapat masalah autokorelasi pada model tersebut.

\section{d. Uji Multikolinieritas}

Tabel 3.

Hasil Uji Multikolinieritas

\begin{tabular}{|l|ll|}
\hline Variable & VIF & l/VIF \\
\hline $\begin{array}{l}\text { Pembiayaan bank } \\
\text { syariah }\end{array}$ & 4.33 & 0.231025 \\
$\begin{array}{l}\text { Pembiayaan bank } \\
\text { konvensioanal } \\
\text { UMKM }\end{array}$ & 5.16 & 0.193671 \\
Intervening syariah & 4.73 & 0.211296 \\
Intervening konven & 5.85 & 0.170895 \\
\multicolumn{2}{|l}{ Mean VIF = 4.38 } \\
\hline
\end{tabular}

Sumber: data diolah peneliti

dapat dilihat bahwa perhitungan nilai korelasi semua kombinasi antara tiga variabel. Dan seluruh variabel menunjukkan nilai rata-rata VIF sebesar $4.38 \quad(<10)$ dan 1/VIF >0.1. Sehingga dari hasil tabel diatas dapat disimpulkan bahwa model regresi linier bebas gejala multikolinieritas dan lolos dari uji asumsi klasik multikorelasi.

Hasil Pengujian Analisis Jalur atau Path

\section{Analysis}


Nurreza, et al/Jurnal Ekonomi Syariah Teori dan Terapan Vol. 6 No. 1 Januari: 125-141; PERAN BANK SYARIAH

DALAM MENGGERAKKAN MOBILITAS SOSIAL (STUDI KASUS: PENGARUH PEMBIAYAAN BANK SYARIAH DAN BANK KONVENSIONAL TERHADAP PENYERAPAN TENAGA KERJA DI UMKM MELALUI PEMBIAYAAN UMKM DI INDONESIA)

Tabel 4.

Hasil Regresi Analisis Jalur

\begin{tabular}{|c|c|c|c|c|c|}
\hline Variabel & Coef & $\begin{array}{l}\text { Std. } \\
\text { Err. }\end{array}$ & $\dagger$ & $\begin{array}{c}P>1 \\
\dagger \mid\end{array}$ & Beta \\
\hline $\begin{array}{c}\text { Pembiaya } \\
\text { an bank } \\
\text { syariah } \\
\text { (X1) }\end{array}$ & $\begin{array}{c}- \\
.0024 \\
08\end{array}$ & $\begin{array}{l}.007 \\
9562\end{array}$ & $\begin{array}{c}- \\
0.3 \\
0\end{array}$ & $\begin{array}{c}0.76 \\
4\end{array}$ & $\begin{array}{c}- \\
.09338 \\
07\end{array}$ \\
\hline $\begin{array}{l}\text { Pembiaya } \\
\text { an bank }\end{array}$ & .0182 & .021 & 0.8 & 0.40 & .28442 \\
\hline $\begin{array}{c}\text { konvensioa } \\
\text { nal (X2) }\end{array}$ & 199 & 5864 & 4 & 6 & 06 \\
\hline UMKM (X3) & $\begin{array}{c}1.962 \\
397\end{array}$ & $\begin{array}{l}.746 \\
5181\end{array}$ & $\begin{array}{c}2.6 \\
3\end{array}$ & $\begin{array}{c}0.01 \\
4\end{array}$ & $\begin{array}{c}.52528 \\
35\end{array}$ \\
\hline Intervening & 11.76 & 21.0 & 0.5 & 0.58 & .18066 \\
\hline (Z1) & 999 & 1829 & 6 & 0 & 01 \\
\hline $\begin{array}{c}\text { Intervening } \\
\text { (Z2) }\end{array}$ & $\begin{array}{c}- \\
.0133 \\
961\end{array}$ & $\begin{array}{l}42.0 \\
9915\end{array}$ & $\begin{array}{c}- \\
0.0 \\
0\end{array}$ & $\begin{array}{c}1.00 \\
0\end{array}$ & $\begin{array}{c}- \\
.00011 \\
41\end{array}$ \\
\hline Cons & $\begin{array}{c}.0004 \\
698\end{array}$ & $\begin{array}{l}.000 \\
448\end{array}$ & $\begin{array}{c}1.2 \\
0\end{array}$ & $\begin{array}{c}0.30 \\
3\end{array}$ & \\
\hline
\end{tabular}

Hasil analisis regresi analisis jalur seperti pada tabel 4.5 diatas dapat ditulis persamaan regresi yaitu sebagai berikut:

$Y=0,0004698+(-$
$0,0933807 \times 1)+0,2844206 \times 2+0,5252835 \times 3+0$,
$1806601 Z 1+(-0,0001141 Z 2)$

Nilai konstanta sebesar 0,0004698, hal ini berarti bahwa tenaga kerja akan sebesar 0,0004698 jika pembiayaan bank syariah, pembiayaan bank konvensional, dan UMKM sama dengan nol.

\section{Koefisien Jalur}

Tabel 5.

Moderated Regression Analysis

\begin{tabular}{|lll|r|}
\hline & & & Estimate \\
\hline Tenaga & $<$ & Pembiayaan & \\
Kerja & - & bank syariah & -.0933807 \\
& - & & \\
Tenaga & $<$ & Pembiayaan & \\
Kerja & -- & bank & .2844206 \\
& - & konvensional & \\
Tenaga & $<$ & & \\
Kerja & -- & UMKM & .5252835 \\
Tenaga & - & & \\
Kerja & -- & Intervening & .1806601 \\
Tenaga & - & & \\
Kerja & -- & Intervening & \\
& - & & \\
\hline
\end{tabular}

Sumber: data olah stata versi 14

1.Jika variabel pembiayaan bank syariah berubah maka akan menyebabkan perubahan pada variabel tenaga kerja. Tanda negatif menunjukkan perubahan yang tidak searah, yaitu jika pembiayaan bank syariah meningkat maka tenaga kerja juga akan menurun, dan juga sebaliknya dengan nilai koefisien jalur sebesar -.0933807 2.Jika variabel pembiayaan bank konvensional berubah maka akan menyebabkan perubahan pada variabel tenaga kerja. Tanda positif menunjukkan 
Nurreza, et al/Jurnal Ekonomi Syariah Teori dan Terapan Vol. 6 No. 1 Januari: 125-141; PERAN BANK SYARIAH

DALAM MENGGERAKKAN MOBILITAS SOSIAL (STUDI KASUS: PENGARUH PEMBIAYAAN BANK SYARIAH DAN BANK KONVENSIONAL TERHADAP PENYERAPAN TENAGA KERJA DI UMKM MELALUI PEMBIAYAAN UMKM DI INDONESIA)

perubahan yang searah yaitu jika pembiayaan bank konvensional meningkat maka tenaga kerja juga akan meningkat, dan juga sebaliknya dengan nilai koefisien jalur sebesar .2844206

3.Jika variabel UMKM berubah maka akan menyebabkan perubahan pada variabel tenaga kerja. Tanda positif menunjukkan perubahan yang searah yaitu jika UMKM meningkat maka tenaga kerja juga akan meningkat, dan juga sebaliknya dengan nilai koefisien jalur sebesar .5252835

4.Jika variabel intervening 1 berubah maka akan menyebabkan perubahan pada variabel tenaga kerja. Tanda positif menunjukkan perubahan yang searah yaitu jika intervening 1 meningkat maka tenaga kerja juga akan meningkat, dan juga sebaliknya dengan nilai koefisien jalur sebesar 1806601

5.Jika variabel intervening 2 berubah

maka akan menyebabkan perubahan pada variabel tenaga kerja. Tanda negatif menunjukkan perubahan yang tidaksearah, yaitu jika intervening 2 meningkat maka tenaga kerja juga akan menurun, dan juga sebaliknya dengan nilai koefisien jalur sebesar -.0001141

\section{Analisis Koefisien Determinasi}

Koefisien determinasi dilihat dari nilai $\mathrm{R}$ squared yang menunjukkan besarnya pengaruh atau kontribusi antara variabel eksogen terhadap variabel endogen, variabel eksogen terhadap intervening, variabel intervening terhadap endogen.
Pengujian koefisien determinasi dalam penelitian ini dilakukan dengan alat uji stata versi 14. hasil dari R-squared dalam penelitian ini sebesar 0.3622. angka ini menunjukkan bahwa variabel eksogen dan variabel intervening mampu menjelaskan sebesar $36 \%$ terhadap variabel endogen, sisanya yaitu sebesar $64 \%$ dijelaskan oleh variabel lain di luar model yang diteliti.

\section{Pembuktian Hipotesis}

Untuk menentukan ada tidaknya pengaruh variabel eksogen terhadap endogen, eksogen terhadap intervening, dan intervening terhadap endogen, digunakan ketentuan melihat melihat dari level of significant $=0,05$. jika nilai signifikansi $<0,05$ maka ada pengaruh signifikan pengaruh variabel eksogen terhadap endogen, eksogen terhadap intervening, intervening terhadap endogen, begitu juga sebaliknya. 
Nurreza, et al/Jurnal Ekonomi Syariah Teori dan Terapan Vol. 6 No. 1 Januari: 125-141; PERAN BANK SYARIAH

DALAM MENGGERAKKAN MOBILITAS SOSIAL (STUDI KASUS: PENGARUH PEMBIAYAAN BANK SYARIAH DAN BANK KONVENSIONAL TERHADAP PENYERAPAN TENAGA KERJA DI UMKM MELALUI PEMBIAYAAN UMKM DI INDONESIA)

Tabel 6.

Hasil Uji Parsial

\begin{tabular}{|c|c|c|c|}
\hline Variabel & T hitung & t tabel | & $P>\mid \dagger$ \\
\hline \multicolumn{4}{|l|}{ Pembiayaan } \\
\hline bank syariah & -0.30 & 2.03011 & 0.764 \\
\hline$(X 1)$ & & & \\
\hline \multicolumn{4}{|l|}{ Pembiayaan } \\
\hline bank & 0.84 & 2.03011 & 0.406 \\
\hline konvensioanal & & & \\
\hline & & & \\
\hline UMKM (X3) & 2.63 & 2.03011 & 0.014 \\
\hline $\begin{array}{l}\text { Intervening } \\
\text { (Z1) }\end{array}$ & 0.56 & 2.03011 & 0.580 \\
\hline $\begin{array}{c}\text { Intervening } \\
\text { (Z2) }\end{array}$ & -0.00 & 2.03011 & 1.000 \\
\hline Cons & 1.05 & & 0.303 \\
\hline
\end{tabular}

Sumber: data olah stata versi 14

Pengujian hipotesis pertama:

Pembiayaan bank syariah tidak berpengaruh terhadap penyerapan tenaga kerja melalui pembiayaan usaha kecil, mikro, dan menengah (UMKM) di Indonesia. Pengujian ini dengan menggunakan uji parsial, dimana nilai $\dagger$ hitung intervening sebesar 0.56 lebih kecil daripada $†$ tabel sebesar 2.03011 dengan probabilitas sebesar 0.580 (lebih besar daripada yaitu 5\%), sehingga $\mathrm{HO}$ diterima atau Ha ditolak, yang berarti pembiayaan bank syariah melalui variabel intervening tidak berpengaruh signifikan terhadap tenaga kerja.

Pengujian hipotesis kedua:

Pembiayaan bank konvensional tidak berpengaruh terhadap penyerapan tenaga kerja melalui pembiayaan usaha kecil, mikro, dan menengah (UMKM) di Indonesia. Pengujian ini dengan menggunakan uji parsial, dimana nilai † hitung intervening sebesar -0.00 lebih kecil daripada $\dagger$ tabel sebesar 2.03011 dengan probabilitas sebesar 1.000 (lebih besar daripada yaitu 5\%), sehingga $\mathrm{HO}$ diterima atau $\mathrm{Ha}$ ditolak, yang berarti pembiayaan bank syariah dan bank konvensional melalui variabel intervening tidak berpengaruh signifikan terhadap tenaga kerja.

Pengujian hipotesis ketiga:

pembiayaan bank syariah berpengaruh terhadap penyerapan tenaga kerja UMKM di Indonesia. Pengujian ini dengan menggunakan uji parsial, dimana nilai $\dagger$ hitung pembiayaan bank syariah sebesar 0.30 lebih kecil daripada $\dagger$ tabel sebesar 2.03011 dengan probabilitas sebesar 0.764 (lebih besar daripada yaitu 5\%), sehingga $\mathrm{HO}$ diterima atau $\mathrm{Ha}$ ditolak, yang berarti pembiayaan bank syariah tidak berpengaruh signifikan terhadap tenaga kerja.

Pengujian hipotesis keempat:

Pembiayaan bank konvensional berpengaruh terhadap penyerapan tenaga kerja di Indonesia. Nilai † hitung pembiayaan bank konvensional sebesar 0.84 lebih kecil daripada + tabel sebesar 2.03011 dengan probabilitas sebesar 0.406 (lebih besardaripada yaitu 5\%), sehingga HO diterima atau Ha ditolak, yang berarti pembiayaan bank konvensional tidak 
Nurreza, et al/Jurnal Ekonomi Syariah Teori dan Terapan Vol. 6 No. 1 Januari: 125-141; PERAN BANK SYARIAH

DALAM MENGGERAKKAN MOBILITAS SOSIAL (STUDI KASUS: PENGARUH PEMBIAYAAN BANK SYARIAH DAN BANK KONVENSIONAL TERHADAP PENYERAPAN TENAGA KERJA DI UMKM MELALUI PEMBIAYAAN UMKM DI INDONESIA)

berpengaruh signifikan terhadap tenaga kerja.

Pengujian Hipotesi kelima:

Pertumbuhan UMKM berpengaruh terhadap penyerapan tenaga kerja umkm di Indonesia. Pengujian ini dengan menggunakan uji parsial, dimana nilai $\dagger$ hitung UMKM sebesar 3.40 lebih besar daripada † tabel sebesar 2.03011 dengan probabilitas sebesar 0.002 (lebih kecil daripada yaitu 5\%), sehingga HO ditolak atau $\mathrm{Ha}$ diterima, yang berarti UMKM berpengaruh signifikan terhadap tenaga kerja.

\section{KESIMPULAN DAN SARAN}

\section{Kesimpulan}

Simpulan penelitian sebagai berikut:

1.Pembiayaan bank syariah tidak berpengaruh dalam penyerapan tenaga kerja UMKM melalui pembiayaan UMKM di Indonesia.

2.Pembiayaanbank konvensional tidak berpengaruh dalam penyerapan tenaga kerja UMKM melalui pembiayaan UMKM di Indonesia

3.Pembiayaan bank syariah tidak berpengaruh dalam penyerapan tenaga kerja UMKM di Indonesia

4.Pembiayaan bank konvensional tidak berpengaruh dalam penyerapan tenaga kerja UMKM di Indonesia

5.Pertumbuhan UMKM berpengaruh dalam penyerapan tenaga kerja UMKM di Indonesia

\section{Saran}

1.Variabel eksogen yang digunakan dalam penelitian ini hanya sebatas pembiayaan bank syariah dan bank konvensional. Pada penelitian selanjutnya diharapkan memasukkan variabel lainnya yang berpengaruh terhadap penyerapan tenaga kerja

2.Saran untuk peneliti selanjutnya terkait dengan pembiayaan bank syariah adalah memperluas tema penelitian, memfokuskan pada satu bank agar lebih akurat hasil penelitiannya, dan mengupdate tahun penelitian.

3.Untuk Otoritas Jasa Keuangan dan Bank Indonesia sebagai otoritas moneter lebih mengembangkan sistem kebijakan moneter syariah terutama dalam hal yang berkaitan dengan UMKM, karena UMKM merupakan salah satu penggerak pertumbuhan ekonomi dalam sektor riil.

\section{DAFTAR PUSTAKA}

Al-qur'an dan Hadist

Alfiah, Fitriyani Ikmal. Analisis Pengaruh Pembiayaan Syariah Terhadap Pengembangan Usaha Mikro, Kecil, Dan Menengah Di Kota Padang. Skripsi. Diploma Thesis, Universitas Andalas. 2016

Anshori, Muslich \& Sri Iswati.(2009). Metodologi Penelitian Kuantitatif.Surabaya : Airlangga University Press (AUP)

Antonio M. Syafii. 2001. Bank Syariah Dari Teori ke Praktik. Gema Insani Press. Jakarta. 
Nurreza, et al/Jurnal Ekonomi Syariah Teori dan Terapan Vol. 6 No. 1 Januari: 125-141; PERAN BANK SYARIAH

DALAM MENGGERAKKAN MOBILITAS SOSIAL (STUDI KASUS: PENGARUH PEMBIAYAAN BANK SYARIAH DAN BANK KONVENSIONAL TERHADAP PENYERAPAN TENAGA KERJA DI UMKM MELALUI PEMBIAYAAN UMKM DI INDONESIA)

Aysan, Ahmet F, dkk. 2016. Is small the new big? Islamic banking for SMEs in Turkey. Economic Modelling 54 (2016) 187-194.

Budiarto, Rachmawan, dkk. 2016. Pengembangan UMKM: Antara Konseptual dan Pengalaman Praktis. Yogyakarta: Gadjah Mada University Press.

Dongoran, Faisal R, dkk. 2016. Analisis JumlahPengangguran dan Ketenagakerjaan Terhadap Keberadaan Usaha Mikro Kecil dan Menengah di Kota Medan. Jurnal EduTech Vol. 2 No. 2 September 2016

Ghozali, Imam. 2011. "Aplikasi Analisis Multivariate Dengan Program SPSS".

Semarang: Badan Penerbit Universitas Diponegoro.

Hafni, Roswita, \& Ahmad Rozali. (2015). Analisis Usaha Mikro, Kecil, dan Menengah (UMKM) Terhadap Penyerapan Tenaga Kerja di Indonesia. Jurnal Ekonomikawan, 7796.

Hayati, Safaah Restuning. 2014. Peran Perbankan Syariah terhadap Pertumbuhan Ekonomi Indonesia. Jurnal Indo-Islamika, 41-66.

Huda, Aulia Nurul. 2012. The Development of Islamic Financing Scheme for SMEs in a Developing Country: The Indonesian Case. Procedia - Social and Behavioral Sciences 52 ( 2012 ) $179-186$.

Jihad Muhammad Noor. 2014. Analisis Pengaruh Suku Bunga dan Pemberian Kredit Terhadap Unit, Tenaga Kerja dan Omzet UMKM. Skripsi. Jurusan Ilmu Ekonomi, Fakultas Ekonomi dan Bisnis, Universitas Brawijaya.

Kara, Muslimin. 2013. Kontribusi Pembiayaan Perbankan Syariah Terhadap

Pengembangan Usaha Mikro, Kecil, dan Menengah. Ahkam: Jurnal Ilmu Syariah, Vol. XIII, No. 2, 315-322.

Konadi, Win. 2014. Analisis Kredit Investasi Perbankan Terhadap Penyerapan Tenaga Kerja. Jurnal Kebangsaan, Vol.3 No.6

Latan, Hengky. 2014. Aplikasi Analisis Data Statistik Untuk IImu Sosial Sains dengan IBM SPSS. Bandung: Alfabeta.

Nnabu, dkk. 2017. Commercial Bank Credit to Small and Medium Scale Enterprises (SMEs) and Unemployment Reduction in Nigeria. IOSR Journal Of Humanities And Social Science (IOSR-JHSS). Volume 22, Issue 7, Ver. 17 (July. 2017) PP 93102.

Ratna, Indera Irawati Pattinasarany. 2016. Stratifikasi dan Mobilitas Sosial. Jakarta: Yayasan Pustaka Obor Indonesia 
Nurreza, et al/Jurnal Ekonomi Syariah Teori dan Terapan Vol. 6 No. 1 Januari: 125-141; PERAN BANK SYARIAH

DALAM MENGGERAKKAN MOBILITAS SOSIAL (STUDI KASUS: PENGARUH PEMBIAYAAN BANK SYARIAH DAN

BANK KONVENSIONAL TERHADAP PENYERAPAN TENAGA KERJA DI UMKM MELALUI PEMBIAYAAN UMKM DI INDONESIA)

Rejeki, Dwi Prawani Sri \& R. Djoko Hartono. 2009. Strategi Pemecahan Pengangguran di Tengah Krisis Global. Jurnal Stie Semarang.

Ridho, Sari Lestari Zainal. 2013. Perbankan Syariah dan Pengangguran: Suatu Aplikasi Eempiris Teori Search and Matching Model. Jurnal Keuangan dan Perbankan, Vol.17, No.1 Januari 2013, hlm. 156-167.

Sugiyono, 2009, Metode Penelitian Kuantitatif, Kualitatif dan R\&D, Bandung : Alfabeta.

Sugiyono. 2012. Metode Penelitian Kuantitatif Kualitatif dan R\&D. Bandung: Alfabeta.

Sugiyono. 2014. Metode Penelitian Kuantitatif, Kualitatif, dan Kombinasi (Mixed Methods). Bandung : Alfabeta

Suliyanto. 2011. Ekonometrika Terapan: Teori dan Aplikasi dengan SPSS. Yogyakarta: ANDI

Undang-undang Nomor 10 tahun 1998 tentang perbankan

Undang-undang Nomor 20 Tahun 2008 tentang Usaha Mikro, Kecil dan Menengah.

Undang-undang Nomor 21 tahun 2008 tentang perbankan syariah.

Zamroni. 2013.Peran Bank Syariah Dalam Penyaluran Dana Bagi Usaha Mikro Kecil Dan Menengah (UMKM). Iqtishadia: Jurnal Kajian Ekonomi dan Bisnis Islam STAIN Kudus. Vol. 6, No. 2, 225-240. 